\title{
Evaluation of etiological factors in childhood poisonings
}

\section{Çocukluk çağ|l zehirlenmelerine neden olan faktörlerin değerlendirilmesi}

\author{
Utku Aygüineş ${ }^{1}$, Ali Kaya ${ }^{2}$
}

Sivas Cumhuriyet University Faculty of Medicine, Division of Pediatric Hematology-Oncology, Department of Pediatrics, Sivas, Turkey

${ }^{2}$ Department of Pediatrics, Kayseri Training and Research Hospital, Kayseri, Turkey

Corresponding author: Utku Aygüneş, MD., Cumhuriyet University Faculty of Medicine, Division of Pediatric Hematology-Oncology, Department of Pediatrics, Sivas, Turkey

E-mail: utkuayg@gmail.com

Received/Accepted: April 20, 2018 / December 29, 2018

Conflict of interest: There is not a conflict of interest.

\section{SUMMARY}

Objective: Poisoning represents one of the most common medical emergencies in childhood, and epidemiological properties differ from country to country. Thus, special epidemiological surveillance for each country is necessary to determine the problem according to which preventive measures can be taken. The aim of this study was to identify regional, familial, socioeconomic and economic characteristics of intoxications and investigate the factors that may facilitate such intoxications.

Method: 318 poisoning cases aged between 1 month-17 years ( $44 \pm 18$ months on average) who were taken to the Pediatric Emergency Service of Sivas Cumhuriyet University Faculty of Medicine were evaluated retrospectively.

Results: The ratio of poisoning cases to all pediatric emergency admissions was $5.1 \%$. $65.1 \%$ of the cases were males, and the ratio of males to females was 1.8:1. Of the poisoning agents, 66\% (n: 210) were pharmacologic and 34\% (n: 108) were non-pharmacologic agents. The highest rate of poisoning was in the 25 months-5 years of age group (75.2\%), and the most common poisoning agents were drugs. When evaluated by seasons, $40.3 \%$ of the patients referred to the hospital in the summer, $25.2 \%$ in the spring, $18.2 \%$ in the winter and $16.4 \%$ in the autumn. It was determined that $66.2 \%$ of the poisoning cases occurred at home and $33.8 \%$ occurred outside home. Of the poisoning cases, $7.9 \%$ were due to suicide, $\% 11.3$ were due to ignorance, $\% 69.2$ were accidental, $\% 0.6$ were iatrogenic, $\% 0.6$ were due to addiction, \%0.3 were due to exposure, \%1.6 due to adverse effects and \%6.3 were due to other reasons. It was determined that accidental intake of drugs was the most common poisoning agent in our region.

Conclusions: This study will contribute significantly in determining the poisoning profile of the region, raising awareness of healthcare personnel and the society and taking preventive measures.

Keywords: childhood, demographic characteristics, intoxication.

\section{ÖZET}

Amaç: Zehirlenmeler çocukluk çağının en sık karşılaşılan tıbbi acillerinden olup epidemiyolojik özellikleri yaşanılan bölgenin özelliklerine göre değişmektedir. Bu aynı zamanda yöreye özel önleyici tedbirler almak için gereklidir. Bu nedenle Çocuklardaki zehirlenme vakalarının ailevi, sosyokültürel ve ekonomik özelliklerinin incelenmesi, çocuklarda zehirlenmelerin meydana gelişini kolaylaştırabilecek olan faktörlerin araştırılması amaçlanmıştır.

Yöntem: Bu çalışmada; Sivas Cumhuriyet Üniversitesi Tıp Fakültesi Çocuk Sağlığı ve Hastalıkları Çocuk Acil Servisi'ne getirilen yaşları 1 ay-17 yaş arasında değişen (ortalama $44 \pm 18$ ay) 318 zehirlenme olgusu geriye dönük olarak değerlendirildi.

Bulgular: Zehirlenme olgularının tüm acil başvurularına oranı \% 5.1 idi. Olguların \% 65.1'i erkek ve erkek:kız oranı 1.8 : 1'di. Zehirlenme etkenlerinin \%66 's1 (n: 210) farmakolojik ajanlar, \%34'ü (n: 108) ise farmakolojik olmayan ajanlard1. Zehirlenmelerin en sık görüldüğü yaş grubu 25 ay - 4 yaş (\%75.2) ve bu dönemde en sik zehirlenme etkeni ilaçlar idi. Mevsime göre dağılımda hastaların \% 40.3'ü yazın, \%25.2'si ilkbaharda, \% 18.2'si kışın ve \% 16.4'ü sonbaharda başvurmuştu. Zehirlenmelerin \%66.2'sinin ev içi, \%33.8'inin ev dışı ortamda gerçekleştiği belirlendi. 
Olgularının \%10.1'u intihar amaçlı, \%11.3 bilgisizlik, \%69.2'i kaza sonucu, \%0.6 iyatrojenik, \%0.6 bağımlılık, \%0.3 maruziyet, \%1.6 yanetki, \%6.3 diğer sebeplerden meydana gelmişti.

Sonuç: Bu çalışmanın bölgenin zehirlenme profilinin belirlenmesine, sağılı personeli ve toplumun bilgilendirilmesine ve koruyucu önlemlerin alınmasına katkısı olacaktır.

Anahtar sözcükler: çocukluk çağı, demografik özellikler, zehirlenme.

\section{INTRODUCTION}

Having a significant place among the emergency illnesses seen in children, poisonings are among preventable causes of morbidity and mortality. In the studies conducted in our country, it was determined that poisonings rank as the second childhood accidents following traumas. Poisoning agents vary by countries, geographical regions, seasons, social traditions and level of education ${ }^{1}$. Identification of clinical and epidemiological characteristics of poisonings will be a guide to determine both the suitable clinical approach and the measures that may be taken for protection. Therefore, our study aimed to evaluate the epidemiological and clinical characteristics of poisoning cases referred to the Pediatric Emergency Service of Sivas Cumhuriyet University Faculty of Medicine, to which patients from Sivas city and neighboring cities apply.

\section{MATERIAL AND METHODS}

In this study, the files of 318 poisoning cases referred to the Pediatric Emergency Service of Sivas Cumhuriyet University Faculty of Medicine were examined retrospectively. The patients were evaluated by age, gender, date of application, the residential area where they come from, the duration between poisoning and application to hospital, poisoning agents, manner of occurrence of poisoning, route of administration, symptoms caused by intoxication and findings, methods of treatment administered, duration of monitoring in the hospital and results of treatment. In statistical evaluations, two tests were used, which are Pearson Correlation analysis and variance analysis.

\section{RESULTS}

In the three-year period when the study was conducted, the ages of 318 patients taken to our polyclinic varied between 1 month and 17 years. Of the patients, $217(65 \%)$ were male and 111 $(35 \%)$ were female. The ratio of male patients to female patients was $1.95 / 1$. It was seen that poisonings were the most common in the 2-4 age group $(75.2 \%, \mathrm{n}: 239)$. Poisonings in the age group 2-4 are more common among male patients, and the ratio of male patients to female patients was 2.1/1 (Table 1).

Table 1. The distribution of patients according to gender.

\begin{tabular}{|ll|c|c|}
\hline & Gender & $\mathrm{n}$ & $\%$ \\
\hline Male & $0-1$ & 6 & 2,9 \\
& $2-4$ & 162 & 78,3 \\
& $5-12$ & 29 & 14,0 \\
& 13 ve üzeri & 10 & 4,8 \\
& Total & 207 & 100,0 \\
& & 8 & 7,2 \\
Female & $0-1$ & 77 & 69,4 \\
& $2-4$ & 3 & 2,7 \\
& $5-12$ & 23 & 20,7 \\
& 13 ve üzeri & 111 & 100,0 \\
\hline
\end{tabular}

Of the poisoning cases, $53.8 \%$ (n: 171) lived in Sivas and neighboring cities, $25.8 \%$ lived in towns and $20.4 \%$ lived in villages. 
Upon examination of the cases by the season of admission, it was determined that poisonings occurred most commonly the summer $(40.3 \%$; n:
128), followed by the spring with $25.2 \%$, the winter with $18.2 \%$ and the fall with $16.4 \%$ (Table 2).

Table 2. The distribution of patients according to seasons.

\begin{tabular}{|c|c|c|}
\hline Season & $\mathrm{n}$ & $\%$ \\
\hline Summer & 128 & 40,3 \\
Winter & 58 & 18,2 \\
Autumn & 52 & 16,4 \\
Spring & 80 & 25,2 \\
Total & 318 & 100,0 \\
\hline
\end{tabular}

$69.2 \%$ of the poisoning cases were accidental, $11.3 \%$ were due to ignorance, $10.1 \%$ were due to suicide, $0.6 \%$ were iatrogenic, $\% 0.6$ were due to addiction, $\% 0.3$ were due to exposure, $\% 1.6$ due to adverse effects and \%6.3 were due to other reasons (Table 3).

Table 3. Causes of the poisoning cases.

\begin{tabular}{|l|c|}
\hline Reasons & Olgu say1s1 - (Yüzde \%) \\
\hline Accidental & $(69.2)-219$ \\
\hline Ignorance & $(11.3)-36$ \\
\hline Suicide & $(10.1)-32$ \\
\hline Adverse effect & $(1.6)-5$ \\
\hline Iatrogenic & $(0.6)-2$ \\
\hline Addiction & $(0.6)-2$ \\
\hline Exposure & $(0.3)-1$ \\
\hline Other reasons, & $(6.3)-21$ \\
\hline
\end{tabular}

Examination of the poisoning cases by age groups showed that $75.2 \%, 10.4 \%, 10.1 \%$ and $4.4 \%$ of the drug poisoning cases occurred in the age groups 2-4, 12-18, 5-12 and 0-1, respectively. Upon examination of poisoning agents by the age groups, it was seen that drugs were the most common poisoning agents in all age groups (Table 4 ).

Table 4. The distribution of patients according to age groups.

\begin{tabular}{|c|c|c|}
\hline & & \\
Age & $\mathrm{n}$ & $\%$ \\
\hline $0-1$ & 14 & 4,4 \\
$2-4$ & 239 & 75,2 \\
$5-12$ & 32 & 10,1 \\
$13-18$ & 33 & 10,4 \\
Total & 318 & 100,0 \\
\hline
\end{tabular}


hours. It was determined that approximately half

within the first 6 hours (Table 5).

of the cases $(56.2 \%)$ referred to the hospital

Table 5. Time for admission to the emergency service.

\begin{tabular}{|c|c|}
\hline Time (hours) & $\mathrm{n}-(\%)$ \\
\hline $0-1$ & $62-(19.4)$ \\
\hline $1-2$ & $123-(38.6)$ \\
\hline $2-6$ & $179-(56.2)$ \\
\hline $6-24$ & $46-(62.2)$ \\
\hline
\end{tabular}

The agents resulting in poisoning are shown in the table below (Table 6). The poisoning agents were divided into 8 groups (Table 7). Drugs that are the most common poisoning agent were also divided into 7 subgroups. 66\% (n:210) of the poisoning agents were pharmacological agents whereas 34\% (n:108) were non-pharmacological agents. The most common pharmacological poisoning agent was paracetamol (20.1\%), which was followed by multiple drug intake $(9.1 \%)$, amitriptyline $(6.9 \%)$, aspirin $(5.7 \%)$, risperidone $(3.1 \%)$, iron $(2.5 \%)$ and the other group that consists of a wide spectrum of other drugs
(18.6\%). Non-pharmacological poisoning agents consisted of industrial-agricultural products (26.6\%), followed by rat poison (21.9\%), mushrooms (13.3\%), toxic gasses (13.3\%), insect stings and bites and snake bites $(7.7 \%)$ and others $(10 \%)$. In five patients $(1.6 \%$ of all agents), the poisoning agent could not be identified. Upon examination of the poisoning agents by age groups, it was seen that the most common reason of poisoning was drug intake in all age groups (age $0-1$, age $2-4$, age 5-12, age 13 and over).

Table 6. The category of poisoning agents involved.

\begin{tabular}{|c|c|c|}
\hline Agents & $\mathrm{n}$ & $\%$ \\
\hline Drugs & 213 & 67,0 \\
\hline Mushroom & 14 & 4,4 \\
\hline Food intoxication & 7 & 2,2 \\
\hline $\begin{array}{l}\text { Industrial-agricultural } \\
\text { products }\end{array}$ & 28 & 8,8 \\
\hline Insect stings/bites & 8 & 2,5 \\
\hline Rat poison & 23 & 7,2 \\
\hline Toxic gasses & 14 & 4,4 \\
\hline Other & 11 & 3,5 \\
\hline Total & 318 & 100,0 \\
\hline
\end{tabular}


Table 7. The most common agents of poisoning associated with drugs.

\begin{tabular}{|l|c|c|}
\hline Drugs & $\mathrm{n}$ & $\%$ \\
\hline paracetamol & 64 & 20,1 \\
multiple drug intake & 29 & 9,1 \\
aspirin & 18 & 5,7 \\
amitriptyline & 22 & 6,9 \\
risperidone & 10 & 3,1 \\
iron & 8 & 2,5 \\
Other & 59 & 18,6 \\
Total & 210 & 66,0 \\
& & \\
\hline
\end{tabular}

The most common routes of administration of the poisoning agents were oral (90.3\%), inhalational (4.7\%), insect stings and bites $(2.5 \%)$, dermal $(2.5 \%)$, oral and inhalational $(0.9 \%)$, dermal and ocular $(0.5 \%)$, oral and dermal $(0.3 \%)$, dermal and inhalational $(0.3 \%)$, oral, ocular and inhalational (0.2\%), respectively.

The symptoms and findings identified in our cases are given in the table in order of frequency.
Most of the patients (45\%; n: 146) were asymptomatic whereas nausea and vomiting were detected in $44 \%$ of the cases (n: 144), being the most common complaint symptom among the patients. The symptoms and findings identified in our cases are given in the table in order of frequency. Confusion (30\%), tachycardia (14\%), local dermal findings (13\%) and miosis $(10 \%)$ were among the other most common symptoms and findings (Table 8).

Table 8. Clinical and physical examination parameters of poisoned cases.

\begin{tabular}{|l|c|}
\hline \multicolumn{1}{|c|}{ Findings } & $\mathrm{n}-\%$ \\
\hline Asymptomatic & $146-45$ \\
\hline Nausea and vomiting & $144-44$ \\
\hline Confusion & $98-30$ \\
\hline Tachycardia & $45-14$ \\
\hline Local dermal findings & $44-13$ \\
\hline Miosis & $34-10$ \\
\hline Dehydratation & $30-9$ \\
\hline Diarrhea & $29-9$ \\
\hline Mydriasis & $28-8$ \\
\hline DTR'de Azalma & $28-8$ \\
\hline Distony & $24-7$ \\
\hline Dyspnea & $24-7$ \\
\hline Flushing & $20-6$ \\
\hline Tachypnea & $20-6$ \\
\hline Agitation & $19-5$ \\
\hline Bradycardia & $19-5$ \\
\hline Ataxia & $6-1$ \\
\hline Cyanosis & $6-1$ \\
\hline Respiratory arrest & $5-1$ \\
\hline Cogwheel rigidity & $1-1$ \\
\hline Edema & $1-1$ \\
\hline
\end{tabular}


Poisonings occurred within 12-17 hours in 169 cases $(53.1 \%), 18-23$ hours in 81 cases $(25.5 \%)$,
6-11 hours in 57 cases (17.9\%), and 0-5 hours in 11 cases $(3.5 \%)$ (Table 9$)$.

Table 9. The distribution of patients according to time.

\begin{tabular}{|c|l|l|}
\hline Time (hours) & \multicolumn{1}{|c|}{$\mathrm{n}$} & \multicolumn{1}{c|}{$\%$} \\
\hline $0-5$ & 11 & 3,5 \\
$6-11$ & 57 & 17,9 \\
$12-17$ & 169 & 53,1 \\
$18-23$ & 81 & 25,5 \\
Total & 318 & 100,0 \\
\hline
\end{tabular}

Examination of the suicidal poisoning cases revealed that the most common poisoning agents were multiple drug administration (45.9\%), antidepressants $(33.1 \%)$ and antiepileptic drugs $(21 \%)$. $52.6 \%$ of the poisoning cases were administered gastric lavage and/or activated charcoal; and $20.2 \%$ were given antidotes. It was found out that $14.6 \%$ of the cases were given yoghurt, ayran, water, milk or similar drinks by their families at home whereas $3.4 \%$ were induced to vomit before being brought to the hospital. It was seen that, later, $30.8 \%$ of the patients were kept under emergency monitoring, $57.5 \%$ were admitted to the emergency service, $7.2 \%$ were admitted to intensive care unit, and $4.4 \%$ were monitored in pediatric surgery service (Table 10).

Table 10. Monitoring services of poisoning cases.

\begin{tabular}{|l|c|}
\hline \multicolumn{1}{|c|}{ Services } & $\mathrm{n}-(\%)$ \\
\hline Pediatrics service & $182(57.5)$ \\
\hline Emergency service & $95(30.8)$ \\
\hline Intensive care unit & $22(7.2)$ \\
\hline Pediatric surgery service & $19(4.4)$ \\
\hline
\end{tabular}

\section{DISCUSSION}

People are exposed to several natural or artificial toxic agents in daily life as the technological advancements gather speed. Such toxic agents may include drugs, food additives, industrial chemical substances, environmental pollutants (exhaust gas, pesticides), natural toxins (plant and animal origin), or domestic toxins (pesticides, drugs, solvents, detergents, etc.). Poisoning cases are encountered most commonly in the childhood. As a matter of fact, American Association of Poison Control Centers (AAPCC) reported in 1991 that, of the poisoning cases compiled from 72 poison control centers in 1990, 66\% occurred in the pediatric age, $82 \%$ occurred due to exposure to non-toxic agents, $17 \%$ were minor poisonings, and $\% 1$ were mild or life-threatening poisonings ${ }^{1}$. In our study, the recovery rate and mortality rate were detected as $99 \%$ and $1 \%$, respectively. The mortality rates were reported as
3.9\% by Uçar et. al. (the Black Sea Region), 3.9\% by Tunç et. al. (Isparta), $1.7 \%$ by Gacar et. al. (Trabzon), $4.9 \%$ by Hincal et. al. (Ankara), and $2.7 \%$ by Orbak et. al. (Erzurum) ${ }^{2}$. Whereas the mortality rate is $1 \%$ in developed countries, mortality continues to be an issue and stays at an elevated rate in developing countries such as ours. Today, preventive measures to be taken and timely and appropriate treatment approaches have become even more important due to the increasing awareness of the issue and frequency of the poisoning cases.

In our study, the ratio of poisoning cases to all emergency service admissions was found to be $5.1 \%$. In similar studies conducted in our country, this ratio varies between 1.1 and $2.7 \%^{3}$. In different countries across the world, this ratio varies between 0.9 to $11.9 \% \%^{4-7}$. The most significant reasons why the ratio in our study is lower may be that patients are now able to directly 
apply to tertiary healthcare establishments and emergency doctors or pediatricians in both our city and neighboring cities are mindful of referring poisoning cases to university hospitals.

$80 \%$ of the poisoning cases in childhood occur in children aged under $6^{8}$. It was detected that; out of 2175 poisoning cases admitted to the Poison Control Center of the Ministry of Health Presidency of Refik Saydam Health Center within a one-year period in the year 1988, $857(39.3 \%)$ were aged between $0-12$ and $59 \%$ of these cases were in age 1-3 group 9 . Similarly, the average age of the cases aged under 5 in our study varied between $49 \pm 28$ months, and $79.6 \%$ of them consisted of children aged under five. Accidental poisonings are common in this age group due to increasing motor skills in addition to curiosity to explore and learn and hand-mouth activity ${ }^{10}$. Furthermore, the most important reasons include the fact that inattentive and insensible family members may leave around drugs or other toxic substances in easily accessible places, store drugs not in their own containers, store cleaning agents in drink containers and not have sufficient control over their children.

In our study, it was determined that poisonings occur in male children more commonly $(65.1 \%$ in males; a ratio of 1.8:1 to females) similar to other publications ${ }^{11}$. Male children make up the majority of the cases aged 1-6, constituting the majority of the poisoning cases by age. In a similar study conducted on 323 cases, it is reported that nearly half of the poisoning cases occur in children aged between 13 month and 4 years and the occurrence is more common in males ${ }^{12}$. In general, it could be said that accidental poisonings are more common in children aged 1-6 and male children experience poisonings relatively more commonly. Female children constitute the majority of the suicidal poisoning cases, which usually occur during adolescence. Erkal et. al. set forth that the most common reasons of poisonings in children aged $0-6$ are leaving drugs within reach of children $(49.5 \%)$ and leaving cleaning agents that are not stored in their original containers within reach of children $(17.5 \%)^{13}$. Similar to previous studies, poisonings that occurred by age one were less than in other age groups ${ }^{14,15}$. The poisonings in this age group rather occur when family members accidentally administer a drug to the child and in cases of toxic gas inhalation, which results in intoxication of all family members. In three of our cases $(0.6 \%)$, drugs were administered to children by their mothers accidentally and in repetitive doses; and these cases were seen in children aged under 1 .
$10.1 \%$ of the poisoning cases were suicidal whereas $69.2 \%$ was accidental. 30 out of 32 cases that administered drugs for suicide were aged 1217 while 2 cases were aged $6-11$; and $78.1 \%$ of the cases comprised of girls. In the adolescence, mental and physical changes, domestic disputes, low performance at school, troubles in relationships with friends, and loss of a relative are included among the factors facilitating the tendency to commit suicide. As also seen in our study, the intake of multiple drugs is a common story in suicide attempts. The results of other studies conducted in our country also supported our finding ${ }^{16}$. It was determined that, in suicidal poisoning cases in our study, $45.9 \%$ took multiple drugs, $33.1 \%$ took antidepressants and $21 \%$ took antiepileptic drugs. Therefore, cases attempting suicide and their parents were signed up for psychological treatment programs.

$34 \%$ (n: 108) of all poisoning cases occurred via pharmacological agents whereas 66\% (n: 210) occurred via non-pharmacological agents. Nonpharmacological poisonings occurred due to industrial-agricultural products $(26.6 \%)$, followed by rat poison $(21.9 \%)$, mushrooms $(13.3 \%)$, toxic gasses (13.3\%), insect stings and bites and snake bites $(7.7 \%)$, and other reasons $(10 \%)$. In several studies conducted in our country and the world, drugs rank as the first reason of poisoning in childhood $^{15}$. Accidental poisonings in childhood are reported to be significantly on the decline due to drugs being provided with childproof safety locks or in opaque blister packs ${ }^{17}$. Important reasons of poisonings in our country include the fact that drugs are not kept out of reach of children, which results from families' unawareness of drug poisonings, and that childproof safety locks are not a common practice in our country yet. Many articles in literature emphasize that poisonings mostly occur accidentally ${ }^{10}$. There are studies that suggest significantly high rate of young mothers being responsible for accidental poisonings ${ }^{18}$. This may be important it that it shows that mothers do not have sufficient education and awareness of childcare. Important reasons of poisonings include the fact that such children are mostly left unattended at home, drugs are left within easy reach of children, and drugs are not stored in safety-lock containers. It would be good to raise awareness of families regarding this issue and to use the media for such purposes and to make use of safety-lock containers obligatory to the extent permitted by economic conditions.

Examination of the data of the years 1990-1998 of the pediatric emergency service of our hospital 
revealed that drugs (45.4\%) rank the first among the poisoning agents, which is followed by plants (20.51\%), chemical agents $(7.17 \%)$, pesticides $(7.17 \%)$, foods $(6.15 \%)$, and insect stings and bites and snake bites $(1.02 \%)$. As a result, it was determined that chemical substances (industrialagricultural) are slightly on the rise among the non-pharmacological agents, as also reported in similar studies. Among such substances, household bleach (42\%) ranks as the first, which is followed by oil solvent (7.1\%) and hydrochloric acid (3.5\%). The most important reasons of such increase is the increasingly wide use of such liquids in cleaning, storing such colorless liquids sold in bulk inside plastic bottles or other drink containers and storing them within reach of children. Among the pharmacological poisoning agents, paracetamol $(20.1 \%)$ ranks as the first, followed by multiple drug intake $(9.1 \%)$, amitriptyline $(6.9 \%)$, aspirin $(5.7 \%)$, risperidone $(3.1 \%)$, iron $(2.5 \%)$, and the other group consisting of a wide spectrum of other drugs $(18.6 \%)$. In five cases (1.5\%), the poisoning agent could not be identified. Whereas the frequency of poisoning cases by poisoning agents vary by regions, studies conducted in different regions of our country show that the most frequently encountered pharmacological agents are the drugs that have an effect on the central nervous system. The reason why especially amitriptyline poisoning is frequently seen may be that this drug is frequently used in the clinic, available over the counter and cheap.

The distribution of poisonings by months was similar to other studies ${ }^{19}$ as determined that poisoning cases across Turkey were most common in spring and summer months ${ }^{20}$. The reasons may be that toxic substances are left around during painting and cleaning works at home during these seasons when children also play outside and are not watched over properly while the house is in a shambles. The fact that the toxic substances around are within easy reach of children is a reason for the increase in poisonings. From the distribution of poisoning cases by seasons, $40.3 \%$ of the cases were admitted during summer, $25.2 \%$ in spring, $18.2 \%$ in winter and $16.4 \%$ in fall. Whereas drug is the most common poisoning agent in all seasons, the most common poisoning agent in spring, summer and winter is agricultural-industrial substances, and poisoning by mushrooms is seen most commonly during spring. From the distribution of the poisoning agents by age group, it is seen that drugs again rank as the first in all age groups. Drug poisonings rank as the first in the studies conducted by
Ataturk University in $1994^{21}$, Erciyes University in $1985-1996^{22}$ and Hacettepe University in 1995$2000^{23}$. In the study conducted by Akçay et.al. in Denizli, household cleaning products $(70.6 \%)$ ranked as the first ${ }^{24}$. Other studies carried out in our country indicated that drugs are the most common poisoning agent in child poisonings ${ }^{16}$. Unconscious picking of wild mushrooms growing in the spring particularly in the countryside, which are a good nutritional source, cause in increase in the mushroom poisonings. We believe that inclusion of plant poisonings in our study is because the people of our region take great interest in natural plants such as knotweed and rack growing in our region and these plants can be mixed up with other poisonous plants. Such poisonous plants are grown in this region, which can be frequently confused with knotweed, may most importantly have similar effects with atropine. In our study, no mortality was observed due to such plants. Contrary to previous studies, the number of poisoning cases resulting from consumption of such plants were limited to 5 .

Time of occurrence of poisoning cases is important in determining the causal factors. In our study, it was observed that poisonings mostly occurred in the afternoons and evenings. It is hard to explain why poisoning cases occur during such time period. This may be because parents get tired in later hours of the day and pay less attention to their children or mothers may neglect their children while preparing dinner. In the study carried out by Akçay et. al., it was reported that poisonings occurred mostly in the afternoons and evenings and it took 3.4 hours on average to bring children to the emergency service after poisoning ${ }^{24}$. It is reported that poisoning cases in the United States also mostly occur in the evening hours ${ }^{25}$.

One of the factors that define the efficacy of treatment and prognosis in poisonings is the time that passes until the first treatment is administered. In all cases, the time elapsed until applying to the hospital varied between 10 minutes and 5 days (4.8 days \pm 13 hours on average). The time that passed until applying to the hospital was found out to be 20 minutes to 22 hours (3.9 \pm 4.4 hours on average) in case of pharmacological poisonings and 20 minutes to 3 days (6.8 \pm 16 hours on average) in nonpharmacological poisonings. Socioeconomic conditions, educational level, geographical structure of the region, distance to the healthcare establishment, availability of sufficient number of and sufficiently equipped healthcare 
establishments could be given as the factors influencing such time period.

The treatment plan to be followed in poisoning cases could be summarized as prevention or minimization of absorption of the toxic material, administration of systemic antidotes, changing the metabolism of the toxic agent, acceleration of the elimination from the body and symptomatic treatment. The most common treatment administered in poisoning cases in our study was administration of gastric lavage and/or activated charcoal $(52.2 \%)$. It was found out that $10.6 \%$ of the poisoning cases were given yoghurt, ayran, water, milk or similar drinks by their families at home whereas $4.2 \%$ were induced to vomit before being brought to the hospital. Whereas dilution with water and milk is favorable in case of intake of corrosive materials, it is not recommended for drug poisonings. Even though induced vomiting was a common practice in previous years, it is not routinely practiced any more. While explaining the protective measures during trainings, it is also necessary to raise awareness of the society regarding the first responses to be given at home in case of poisoning. Educational level of families that has a direct effect on the manners and level of knowledge of children is an important factor in poisoning among children. Comparative control group studies are required in this area. There are publications that indicate majority of the families in which a child is poisoned tend to have more than one child ${ }^{22}$. This determination reveals the natural consequence that the more children a family has, the less attention will be paid to each children. Monitoring and treatment of the poisoning cases were mostly conducted in the service. It was seen that the duration of hospitalization was mostly 1 to 5 days. In a previously conducted study, $91 \%$ of the cases were monitored for 24 hours and less in the emergency service ${ }^{26}$. Aji et. al. reported the average hospitalization duration as 12 hours for poisonings ${ }^{22}$. No differences were detected when hospitalization duration was evaluated based on the time passed until arrival at the hospital and the presence of toxicity. The reason for that was approximately $60 \%$ of our cases were brought to the hospital within the first six hours, which did not result in a wide distribution. It could be deduced that the complications may be less when the treatment is started early in cases that are brought to the emergency service early.

\section{CONCLUSION}

In conclusion, mortality rates in poisoning cases vary by regions yet on a decline when compared to previous years. While developments in diagnosis and treatment of poisonings are pleasing, the most proper approach to poisonings is to take protective measures -"the best antidote is education". It would be effective in minimization of poisonings if manufacturing companies pay attention to the levels of toxic substances in drugs and chemical products and drug packages are made childproof. Aside from such standard measures, each region should define their priorities in line with their own epidemiological studies. In addition to the measures to be taken by families, drug manufacturers and doctors, determination of the epidemiological characteristics of poisonings across our country through both retrospective and prospective multi-central studies would contribute greatly in the prevention of childhood poisonings and minimization of mortality and morbidity. We believe that our study will serve as a guide for the measures to be taken as it reflects the epidemiological and clinical characteristics of childhood poisoning cases seen in our region.

\section{REFERENCES}

1. Andiran N, Sarikayalar F. Pattern of acute poisonings in childhood in Ankara: what has changed in twenty years? Turk J Pediatr. 2004; 46: $147-52$.

2. Besbelli N, Yalçınlar O, Yeşilada E. Çocuk zehirlenmeleri konusunda yapılan başvuruların değerlendirilmesi. Yeni Tıp Dergisi 1989; 6: 12632.

3. Özcan $T$, Tosun $A$, İnan $G$, Yendur $G$, Özbek E, Can D, et al. Hastanemize başvuran zehirlenme olgularının değerlendirilmesi. Adnan Menderes Üniversitesi Tıp Fakültesi Dergisi 2002; 3: 5-8.

4. Abed M. Patterns of accidental poisoning in children in Jeddah, Saudi Arabia. Ann Saudi Med 1998; 18: 457-9.

5. Lashley PM, St. John MA. A review of accidental poisoning in Barbados: - a new perspective (1981-1985). Ann Trop Paediatr 1991; 1: 149-53.

6. Dutta AK, Seth A, Goyal PK, et al. Poisoning in children: Indian scenario. Indian J Pediatr 1998; 65: 365-70.

7. Fernando R, Fernando DN. Childhood poisoning in Sri Lanka. Indian J Pediatr 1997; 64: 457-60.

8. Sarıkayalar F. Çocukluk çağında zehirlenme. Katk1 Pediatri Dergisi 1900; 11:201-14 
9. Orbak Z, Selimoğlu MA, Alp H. Erzurum bölgesinde çocuklarda zehirlenme vakalarının değerlendirilmesi. Çocuk Sağlı̆̆ 1 ve Hastalıkları Dergisi 1996; 39: 497-500.

10. Öner N, İnan M, Vatansever Ü, Çağrı Turan, Coşkun Çeltik, Yasemin Küçükuğurluoğlu, et al. Trakya bölgesinde çocuklarda görülen zehirlenmeler. Türk Pediatri Arşivi 2004; 39: 2530 .

11. Kösecik M, Arslan SO, Çelik DL, Soran M. Şanlıurfa'da çocukluk çağı zehirlenmeleri. Çocuk Sağl ve Hastalıkları Dergisi 2001; 44: 235-9.

12. Akbay-Öntürk Y, Uçar B. Eskişehir Bölgesinde çocukluk çağı zehirlenmelerinin retrospektif değerlendirilmesi. Çocuk Sağl ve Hastalık Derg 2003; 46: 103-13.

13. Erkal S, Şafak S. An evaluation of the poisoning accidents encountered in children aged 0-6 years in Kırıkkale. The Turk J Pediatr 2006; 48: 294-300.

14. Derinyol S. 1985-86-87 yıllarında hastanemizde yatan zehirlenme olgularının retrospektif incelemesi. Dr. Sami Ulus Çocuk Hastanesi Pediatri Uzmanlık Tezi. Ankara, 1989.

15. Uçar B, Ökten A, Mocan H. Karadeniz Bölgesinde çocuk zehirlenme vakalarının retrospektif incelenmesi. Çocuk Sağ ve Hastalı Derg 1996; 36: 363-71.

16. Çıtak A, Soysal DD, Yıldırım A, Karaböcüoğlu M, Üçsel R, Uzel N. Çocukluk yaş grubu zehirlenmelerinde tehlikeli değişim. Çocuk Dergisi 2002; 2: 116-20.

17. Thomas YK. Childhood poisoning: The scope for prevention. Vet Human Toxicol 1998; 40: $361-2$.

18. Soyucen E, Aktan Y, Saral A, Akgün N, Numanoğlu AÜ. Sakarya bölgesinde çocukluk çağ1 zehirlenmelerinin geriye dönük değerlendirilmesi. Çocuk Să̆ ve Hastalı Derg 2006; 49: 301-6.

19. Çam H, Kıray E, Taştan Y, Özkan HÇ. İstanbul Üniversitesi Cerrahpaşa Tip Fakültesi Çocuk Sağlığı ve Hastalıkları Anabilim Dalı Acil Servisinde izlenen zehirlenme olguları. Türk Pediatri Arşivi 2003; 38: 233-239.

20. Aji DY, İlter Ö. Türkiye'de çocuk zehirlenmeleri. Türk Pediatri Arşivi 1998; 33: 154-8.

21. Kalaycı AG, Akyüz M, Yılmaz E, Ceviz N, Karakelleoğlu C. Çocukluk çağında zehirlenme nedenleri. Yeni T1p Dergisi 1994; 11: 4-7.
22. Hallaç İK, Poyrazoğlu MH, Aydın K, Kurtoğlu S, Üstünbas HB. Çocukluk Çağı Zehirlenmeleri: Son 10 Y1lın Değerlendirilmesi. Türk Pediatri Arsivi 1996; 31: 337-9.

23. Andıran N, Sarıkayalar F. İhsan Doğramacı Çocuk Hastanesinde son altı yılda izlenen akut zehirlenmeler. Katk1 Pediat Derg 2001; 22: 396408.

24. Akçay A, Gürses D, Özdemir A. Denizli ilindeki çocukluk çağı zehirlenmeleri. Adnan Menderes Üniver Tip Fak Derg 2005; 6: 15-9.

25. Toby L Litovitz, Martin Smilkstein, Linda Felberg, Wendy Klein-Schwartz, Randall Berlin, Jenna L Morgan, 1996 Annual report of the American association of poison control centers toxic exposure surveillance system, The American Journal of Emergency Medicine, 1997; 15: 447500.

26. Biçer S, Sengül A, Yesinel S, Yıldırım S, Uzunoğlu N, Aydoğan G. Pediatrik yaş grubu zehirlenmelerinin tanı, tedavi ve takibinde çocuk acil servisinin etkinliği-2003 Yılı Vakalarının Değerlendirilmesi. Toksikol Derg 2005; 3: 11-17. 